Pamiętnik Literacki 2013, 4, s. 199-224
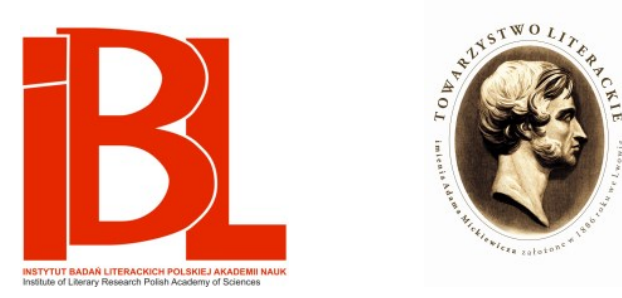

Notatniki Aleksandra Wata z Beinecke

\title{
Library
}

Adam Dziadek 


\section{NOTATNIKI ALEKSANDRA WATA Z BEINECKE LIBRARY}

Notatniki, o których mowa w tytule, znajdują się w zbiorze materiałów archiwalnych autora Ciemnego świecidła w Beinecke Rare Book and Manuscript Library w Yale University (New Haven, USA) i stanowią część Aleksander Wat Papers. Pisane na przełomie lat pięćdziesiątych i sześćdziesiątych XX wieku bruliony są prawdziwym skarbem dla kogoś, kto zajmuje się twórczością Wata. Zostały one „wyłuskane" z bogatego zbioru archiwalnego i są opracowywane w ramach projektu badawczego Notatniki Aleksandra Wata - spiralna nielinearność zapisu ${ }^{1}$. Istnienie notatników stwierdził kilka lat temu Ryszard Zajączkowski w artykule opublikowanym w „Pamiętniku Literackim”, gdzie dokonał ich skróconego omówienia ${ }^{2}$. Jednak nigdy wcześniej nikt nie próbował ich odczytywać, powierzchownie uznając ich nieważność dla całości dzieła Wata lub też - co bardziej prawdopodobne - nie odczytywał ich ze względu na wielkie trudności z odszyfrowaniem. Charakter pisma poety jest niejednorodny, w poszczególnych notatnikach mocno zróżnicowany, tzn. miejscami jest ono czytelne, a czasami traci czytelność i staje się niemal niemożliwe do odszyfrowania. W niektórych wypadkach można przypuszczać, że wynikało to ze stanu zdrowia pisarza, często pogarszającego się gwałtownie samopoczucia, może również zażywanych środków farmakologicznych, ponieważ rozpoczęty czytelnym pismem tekst zaczyna nagle się rozmazywać, pękać syntaktycznie i semantycznie (urywana składnia, liczne skreślenia, poprawki i dopiski na marginesach). Ta sprawa wiąże się ściśle z somatycznym doświadczeniem archiwum, które postaram się dalej objaśnić. Nieczytelność lub utrudniona czytelność wynika też z eliptycznego charakteru zapisu, skrótów myślowych, równoważników zdań często pojawiających się w tekstach. Także i to decyduje o nieuchwytności i enigmatyczności sensów w nich zawartych, które można wyczytać z kontekstu lub też trzeba się ich domyślać opierając się na znajomości faktów biograficznych czy rozległych kontekstów kulturowych.

Teksty zawarte w notatnikach są bardzo silnie zróżnicowane: to zapiski bibliograficzne wskazujące na zainteresowania lekturowe Wata (politologia, socjologia, psychologia, psychoanaliza, historia, filozofia), liczne cytaty, z których część zo-

1 Praca naukowa finansowana w ramach programu Ministra Nauki i Szkolnictwa Wyższego pod nazwą „Narodowy Program Rozwoju Humanistyki” w latach 2011-2014, nr 11H 11000880.

2 R. Z a ją c z k o w s k i, W archiwum Aleksandra Wata. „Pamiętnik Literacki” 2007, z. 1. 
stała później włączona do jego tekstów poetyckich i eseistycznych, fragmenty esejów, szkiców, próby filozoficzne, analizy sowietologiczne (obsesyjnie powraca Stalin jako temat główny), notatki o charakterze dziennikowym opatrzone datami, wypisy z gazet i czasopism. Zdarzają się teksty urwane, niedokończone. W niektórych miejscach widać wyraźnie, że kartki zostały przez autora usunięte, wyrwane. Przeważnie nie są to skończone, dopracowane i gruntownie przemyślane teksty, w większości to pomysły, zarysy, zaledwie kontury, ale pokazują doskonale sposób myślenia i tworzenia, spiralną nielinearność zapisu (liczne powtórzenia, rekurencje tematyczne, podejmowane od nowa te same wątki). To swoisty przykład work in progress - niektóre teksty zawierają dopiski innymi kolorami atramentu, ołówkiem czy różnymi kolorami długopisów, pisakami bądź kredkami, są też miejsca, gdzie zmiana koloru świadczy po prostu o wyczerpaniu atramentu lub wkładu długopisu. Dowodzi to, że Wat wracał do poszczególnych zapisków, weryfikował je i wielokrotnie poprawiał. Tworzą one coś, co można by nazwać „wewnętrzną mapą” tekstów, po której czasami nie da się poruszać bez opracowania legendy znaków i zaznaczeń. Jest to również zbiór oznak (w rozumieniu semiotycznym tego, co pozornie wydaje się mało istotne, a co może uruchomić cały ciąg przyczynowo-skutkowy) i wskazówek, które otwierają wielowymiarową przestrzeń tekstualną.

Charakter zapisu w notatnikach poety ma bezpośredni związek z całością jego dzieła. Są to z reguły notatki ułożone nielinearnie, wiele z nich zawiera kilka wersji tekstowych, liczne zmiany, przekreślenia, podkreślenia, zakreślenia na marginesie (nieraz kilkakrotne), poprawki, dopiski na marginesach, przypisy. Stronice notatników stają się wskutek tego pages performatives - stronicami pisania/czytania. Sposób sporządzania notatek oddaje doskonale model myślenia i działań twórczych. Z jednej strony, są to notatki, które miały posłużyć do dalszej pracy (np. bibliografia pozycji opatrzonych dopiskiem „do Berkeley”, dokąd Wat wyjechał w 1963 roku na zaproszenie The Center for Slavic and East European Studies przy University of California at Berkeley), ale - z innej strony - wśród nich pojawiają się teksty o charakterze wspomnieniowym, teksty autorefleksyjne czy nawet autobiograficzne, opatrzone datami i przypominające dziennikowe zapiski, które z powodzeniem dałoby się dołączyć do Dziennika bez samogłosek.

„Spiralna nielinearność”, wcześniej wspomniana, odzwierciedla w zapisie jedną z najważniejszych cech sposobu rozumowania Wata (widać to wyraźnie w Moim wieku, ale też w wielu innych tekstach, także poetyckich) - chodzi m.in. o gwałtowne przeskakiwanie od tematu do tematu, od myśli do myśli, o ciągłe rekurencje do motywów - jak mogłoby się wydawać - już wyczerpanych i zamkniętych, jednak roztrząsanych w innym miejscu po raz kolejny, w innym świetle, a więc ciągle od nowa wzbogacanych.

Notatniki poety są swoistymi przed-tekstami (w rozumieniu zbliżonym do koncepcji Jeana Bellemin-Noëla w jego pracy Le Texte et l'avant-texte, poświęconej brulionom jednego poematu Oskara Miłosza $\left.{ }^{3}\right)$. Określenie „avant-texte” jest jednym z podstawowych terminów krytyki genetycznej (critique génétique, Ge-

3 J. B elle min-N ö 1, Le Texte et l'avant-texte. Les Brouillons d'un poème de Milosz. Paris 1972. 
netic Criticism ${ }^{4}$ stosowanym powszechnie do dzisiaj. Jego znaczenie w ujęciu Bellemin-Noëla przedstawia się następująco: ,zbiór brulionów, rękopisów, dokumentów, »wariantów«, postrzegany pod kątem tego, co materialnie uprzedza dzieło traktowane jako tekst, i mogący tworzyć wraz z nim system" ". Praca nad notatnikami Wata zbliża się tym samym do krytyki genetycznej i wiąże się z analizą oraz rekonstrukcją procesu pisania - chodzi tu o zapiski w notatnikach przenikające do dzieł tego twórcy. Na podstawie notatników można prześledzić fascynujące transformacje tekstów, począwszy od pierwotnych lektur, analiz dokonanych przez pisarza, notatek, szkiców, luźnych refleksji, aforyzmów, a na różnych wersjach tekstowych kończąc. Na tej zasadzie lektura słynnego i niezwykłego listu Machiavellego do Francesca Vettoriego i znajdujące się w jednym z notatników cytaty z listu przenikną do Pieśni wędrowca. Sam Wat w przypisie do Pieśni VIII wskazuje zresztą to ,źródło”, jednak dopiero w notatnikach widać, jak zostało ono przemyślane, przekształcone i włączone do ostatecznej wersji tekstu. W przepisany przez Wata fragment listu wplecione są wtrącenia w języku polskim, oddające namysł nad samym tekstem Machiavellego. Dopiero po sczytaniu Pieśni VIII $\mathrm{z}$ fragmentami listu zapisanego w notatnikach widać wyraźnie, że cały tekst Wata jest skonstruowany na podstawie tego listu - jest właściwie wariacją na jego temat, a nawet palimpsestem - tekstem na(d)pisanym na tym właśnie liście Machiavellego. Jeśli więc określimy fragmenty notatników Wata jako „przed-teksty”, to zgodnie z założeniami koncepcji Bellemin-Noëla trzeba je czytać wyłącznie wraz z tekstem, do którego się odnoszą ${ }^{6}$.

W innym miejscu notatników odnajdujemy ślady lektury książki Henriego Decugisa, francuskiego ekonomisty i eseisty zajmującego się eugeniką, zatytułowanej Le Vieillissement du monde vivant, z której zaczerpnął Wat motto do siódmej części Snów sponad Morza Śródziemnego. Także i w tym wypadku Wat wskazuje źródło, a jednak notatki, cytaty wypisane ze wspomnianej książki wraz z komentarzami (nawiązania do „człowieka sowieckiego” i do Hoessa) w znaczący sposób rozszerzają relację intertekstualną, której nie bylibyśmy w stanie bez tych wskazówek odtworzyć. Podobnie ma się rzecz z komentowanymi wypisami z utworów Friedricha Hölderlina, Thomasa Edwarda Lawrence'a, Adama Mickiewicza, Wacława Berenta, Sigmunda Freuda i wielu innych. Wszystkie cytaty z publikowanych tu notatników Wata zostały sczytane z odpowiednimi edycjami. Tam, gdzie było to konieczne, wprowadzono drobne korekty i uzupełnienia.

Praktyka sczytywania zapisków notatnikowych z konkretnymi utworami nie

4 Wbrew obiegowym mniemaniom ten model krytyki rozwija się w sposób imponujący także i dziś. Odsyłam w tym miejscu do kilku prac opublikowanych w ostatnich latach: D. Va n $\mathrm{Hu} 11 \mathrm{e}$, Textual Awareness. A Genetic Study of Late Manuscripts by Joyce, Proust, \& Mann. Ann Arbor 2004. - Genetic Criticism. Textes and Avant-textes. Ed. J. D e p p m a n, D. F e r r e r, M. G ro de n. Philadelphia 2004. - Genetic Criticism and the Creative Process. Essays from Music, Literature, Theatre. Ed. W. K i n d e r m a n, J. E. J o n e s. Rochester 2009. Z tego punktu widzenia ważny jest również ostatni numer czasopisma „Europe”, poświęcony M. Proustowi: mówi się w nim wiele na temat rozkwitu ,genetyki tekstualnej” - zob. zwłaszcza artykuł J. R i s s e t Documents d'une écriture infinie. Les carnets, les esquisses („Europe” nr 1012/13〈2013, Août-Septembre〉).

5 B elle min-Noë 1 , op. cit., s. 15.

6 J. B e 11 e m in - N o ë 1, Psychoanalytic Reading and the Avant-texte. W zb.: Genetic Criticism. Textes and Avant-textes, s. 31. 
ma na celu „przyszpilania” sensu danego tekstu, ustalania jakiegoś sensu ostatecznego, definitywnej wykładni znaczenia, lecz raczej umożliwia odsłonięcie pracy sensu, a także rozbudowanie interpretacji, wzbogacenie jej o dodatkowe elementy rozszerzające znaczenie prostej aluzji i - jak mogłoby się zdawać - prostej relacji intertekstualnej. Tak więc krytyka genetyczna, ale nie w skrajnej postaci, w jakiej pojawia się np. u Geerta Lernouta, proponującego „filologię radykalną” (,Radical Philology”) w opozycji do postulowanego przez Paula de Mana ,return to philol$o g y$ ", jak też w opozycji do francuskich badaczy z Institut des textes et manuscrits modernes (ITEM) pracujących nad dziełami Joyce'a w oparciu o teorie Jacques'a Lacana i Jacques'a Derridy ${ }^{7}$. Nie ma tu miejsca na rozstrzyganie sporów, bardzo szczególnych zresztą, bo dotyczących twórczości Joyce'a i analiz jego rękopisów przy wykorzystaniu skrajnie różnych metod. Praca czysto filologiczna w oczywisty sposób leży u podstaw wszelkich działań związanych z odczytywaniem notatników Wata, którego teksty rękopiśmienne zmuszają do pokory, uważnego pochylenia się nad każdym zapisanym znakiem, nad każdym słowem, nad każdym znajdującym się na stronicach notatników zdaniem. Filologia zmusza do odpowiedzialności za słowa, jaką bierze na siebie każdy, kto dokonuje transkrypcji tekstu rękopiśmiennego. Ale, jeśli w trakcie tej pracy dokonuje się jakiegoś ważnego odkrycia, to nie ma powodu, aby nie skorzystać z narzędzi, jakie podsuwa psychoanaliza, dekonstrukcja czy też krytyka genetyczna powiązana z psychoanalizą, jak to się dzieje u Bellemin-Noëla, który łączy pojęcie avant-texte z pojęciem prélogique opracowanym przez Luciena Lévy-Bruhla w jego studium $L a$ Mentalité primitive. Pozycja badawcza opiera się w przypadku notatników Wata nie na tym, że przychodzi się do tekstu wyposażonym w instrumentarium teoretyczne, ale że skupia się w pierwszej kolejności na samym tekście, na pojedynczych słowach rozwijających się w ciągi znaczeniowe. Ten, kto przepisuje tekst rękopiśmienny - tak dzieje się przynajmniej w przypadku Wata - staje na samym początku bezradny przed pustą tablicą, którą mozolnie i z wielkim wysiłkiem musi zapełnić. Dopiero później przychodzi czas na teorie i możliwe rozwinięcia interpretacyjne.

Co do podstaw działań edytorskich - to praca nad notatnikami Wata została powiązana z tzw. „transkrypcją genetyczną”. Jej doskonałym przykładem jest wydana ostatnio "tekstowo-genetyczna" edycja notatnika zawierającego rękopis drugiej części powieści Rilkego Malte ${ }^{8}$. Chodzi, mówiąc w skrócie, o naoczne pokazanie procesu formowania tekstu. Skreślone warianty pozostawia się nie jako przykład negatywny, ślad zaniechanych, nieudanych wariantów tekstu, lecz jako wartość pozytywną, wyraz samoświadomości twórczej, wyrażającej się np. w dążeniu do unikania patosu. Edycja rękopisu Maltego została zrealizowana pod kierunkiem Irmgard M. Wirtz, która zwraca uwagę na element nieciągłości, charakteryzujący ,amfiladę myślowych pomieszczeń” poety, i na przemieszanie

7 G. L e r n o u t, The „Finnegans Wake” Notebooks Radical Philology. W zb.: Genetic Studies in Joyce. Ed. D. H a y m a n, S. S 1 o t e. Amsterdam 1995.

8 R. M. Ri 1 k e, Die Aufzeichnungen des Malte Laurids Brigge. Das Manuskript des ,,Berner Taschenbuches". [1:] Faksimile; [2:] Textgenetische Edition. Hrsg. Th. R i c h t e r, F. K ol p. Göttingen 2012. 
różnych form gatunkowych ${ }^{9}$. Z analogicznymi kwestiami mamy do czynienia w przypadku notatników Wata. Innym przykładem takiej praktyki jest znakomita edycja elektroniczna Madame Bovary Gustave'a Flauberta, opracowana na podstawie rękopisu powieści przez Danielle Girard i Yvana Leclerca ${ }^{10}$. Z kolei na rodzimym gruncie metodologicznie pokrewna jest edycja nieukończonego dramatu Elizy Orzeszkowej Wóz Żagornanta przygotowana przez Iwonę Wiśniewską ${ }^{11}$.

Praca nad notatnikami Wata zmusza do refleksji na temat samego archiwum. Jak je dziś rozumieć, jakie nadać mu znaczenie? Jest to trudne pytanie, które stawiają sobie dziś sami archiwiści, starając się - z różnym skutkiem - określić swój własny status ${ }^{12}$. Na to samo pytanie próbują odpowiadać kulturoznawcy czy filozofowie. W oczywisty sposób archiwum można traktować jako repozytorium faktów, te fakty jednak za każdym razem podlegają lekturze. Istotne jest to, kto tworzy archiwum, ale także to, kto i jak je czyta. Gayatri Chakravorty Spivak przywiązuje do tego szczególną wagę ${ }^{13}$, zajmując się archiwami związanymi z Rani of Sirmur (archiwa stworzone przez białych żołnierzy i administratorów East India Company - powstaje w ten sposób przedmiot reprezentacji, który staje się rzeczywistością Indii i który w istocie ma niewiele wspólnego z samą rzeczywistością, ulegającą całkowitej transformacji pod wpływem kolonializmu). Czytanie archiwum łączy się nierozerwalnie z etyką, z odpowiedzialnością etyczną, jaką bierze na siebie badacz zanurzający się w otchłaniach zbiorów archiwalnych. $Z$ tego punktu widzenia bliskie jest mi szczególnie takie pojmowanie archiwum, jakie przedstawił Jacques Derrida w Mal d'archive:

W znaczeniu enigmatycznym, które przypuszczalnie się wyjaśni (przypuszczalnie, ponieważ z istotnych przyczyn nie może tu być nic pewnego), kwestia archiwum, powtarzam, nie jest kwestią przeszłości, kwestią pojęcia dotyczącego przeszłości, które może lub nie może być do naszej dyspozycji, kwestią archiwizowalnego pojęcia archiwum, ale raczej kwestią przyszłości, prawdziwą kwestią przyszłości, kwestią odpowiedzialności, obietnicy odpowiedzialności za przyszłość. Archiwum: jeśli chcemy wiedzieć, co ma to oznaczać, to dowiemy się o tym dopiero jutro. Być może. W pojęciu archiwum, podobnie jak w religii, w historii i w samej nauce pracuje widmowe posłannictwo, a jest to coś, co wiąże je z pojedynczym doświadczeniem obietnicy ${ }^{14}$.

I rzeczywiście, archiwum to kwestia przyszłości. Archiwum jest miejscem tradycji, miejscem, w którym przeszłość tworzy teraźniejszość i przyszłość. To prawda, że wiąże się z odpowiedzialnością (etyka), z odpowiedzialnością za przy-

9 I. M. W i r t z, Zur lyrischen Gestalt von Rilkes ,,Aufzeichnungen des Malte Laurids Brigge”. „Quarto" nr 35 (2012), s. 22.

${ }^{10}$ Les Manuscripts de „Madame Bovary”. Édition intégrale sur le Web. Na stronie: http://www. bovary.fr/ (dostęp: 29 IX 2013).

${ }^{11}$ E. O r z e s z k o w a, Wóz Żagornanta (nieukończony dramat). Wstęp, oprac. I. W i ś n i e wsk a. Warszawa 2012.

${ }_{12}$ Zob. np. What are the Archives? Cultural and Theretical Perspectives: reader. Ed. L. C r av e n. Aldershot 2008. - Beyond the Archives. Research as a Lived Process. Ed. G. E. K i r s c h, L. R o h a n. Carbondale 2008.

${ }^{13}$ G. S p i v a k, The Rani of Sirmur: An Essay in Reading the Archives. „History and Theory” t. 24 (1985), nr 3 (October), s. 249.

${ }_{14}$ J. Derrid a, Mal d'archive. Paris 1995, s. 55. 
szłość, bo to od nas zależy, jaki nadamy kształt temu, co samo archiwum w sobie kryje. „Archiwum” jest słowem pochodzącym od greckiego ,arkhé”, oznaczającego początek. To właściwe miejsce, od którego rozpoczynają się badania filologiczne, historyczne czy socjologiczne. To jest miejsce, z którego wywodzi się podstawa faktów służących do układania historii i do budowania interpretacji. Archiwum łączy się ściśle z zasadą historyczną i ontologiczną, jest - w pewnym sensie - miejscem, gdzie zaczyna się praca hermeneutyczna.

Archiwum - także to Aleksandra Wata w Beinecke Library - przedstawia sobą fascynujący obiekt badań. Trzeba jednak wysłuchać przestróg, które wypowiada Dominick LaCapra na temat archiwizmu entuzjastycznego i bezkrytycznego. Tego rodzaju archiwizm łączy się często z pretensjami hegemonicznymi, samo archiwum staje się fetyszem, jako takie tworzy substytut tej dawnej rzeczywistości, która dla historyka jest ,zawsze już stracona" ${ }^{15}$.

Przy pracy nad archiwum Wata trudno opanować emocje. Bezpośrednie obcowanie z dokumentami z archiwum wiąże się ze wspomnianym wcześniej doświadczeniem somatycznym. Idzie głównie o sprawę dotyku, dotykania tych samych stronic, zapisanych ręką twórcy. Nie ma w tym naiwności ani emfazy. Dokumenty z archiwum Wata - dokumenty z każdego archiwum - wytwarzają specyficzną aurę, w której dokonuje się i spełnia doświadczenie somatyczne. W oczywisty sposób trzeba oddalić entuzjazm i emocje, trzeba być obiektywnym. Najważniejsze jednak wydaje się to, że transkrypcja i opracowanie tekstów archiwalnych wiążą się ze szczególnym rodzajem powtórzenia. Powtarza się i zaczyna żyć od nowa to, co pozostawało dotąd zamarłe w mroku biblioteki. To sprawa nadzwyczaj istotna, kiedy chodzi o dziedzictwo kulturowe współtworzone przez jednego z najwybitniejszych poetów XX wieku.

Prezentowane materiały znajdują się w Beinecke Rare Book \& Manuscript Library, gdzie opatrzone są sygnaturą GEN MSS 705. Publikujemy je za zgodą Andrzeja Wata.

Wyboru dokonano z 16 notatników, które stanowią podstawę całego projektu. Publikowane tu fragmenty pochodzą z różnych notatników. Data ich powstawania, z pewnymi wyjątkami, w których pojawia się zapis dzienny, jest trudna do ustalenia.

Układ zapisów, często wymuszony formatem notatników, został wiernie oddany. Pisownię i interpunkcję uwspółcześniono.

Podkreślenia autorskie oddano za pomocą druku rozstrzelonego. Przekreślenia zaznaczono pojedynczym przekreśleniem, uzupełniając w nawiasie kwadratowym [ ] hipotetyczny dalszy ciąg zaniechanego słowa. Asteryski $(*)$ oddzielają kolejne stronice notatników. Skróty rozwinięto w nawiasach kwadratowych [ ]. Kursywę w tekstach obcojęzycznych wprowadzili autorzy transkrypcji. Wytłuszczenia (pytajniki, litery po prawej stronie zapisów, poszczególne słowa) pochodzą od Wata, który pogrubiał pismo lub stosował inny kolor. Przypisy do notatek Wata sporządzili autorzy transkrypcji; zostały one ograniczone do minimum ze względu na charakter tej publikacji.

15 D. L a C a p ra, History and Criticism. Cyt. za: S p i va k, loc. cit. 
ALEKSANDER WAT

\section{NOTATNIKI (WYBÓR) \\ TRANSKRYPCJE}

Do sprawdzenia w B[iblioteki] K[ongresu] katalogu

Zieliński

do $\mathrm{B}^{1}$ Russell, [Bertrand], Bols[hevis]m Theory and Practice [The Practice and Theory of Bolshevism, [London 1920, Allen \& Unwin].

Moore, Barrington, [Jr.], Soviet Politics.

The Dilemma of Power. The Role of Ideas [in Social Change].

Cambridge 1951, [Harvard], (Ideology)

[Biesiedovskij, Grigorij] Swanidze [Svanidzé, Boudou, En parlant avec] Staline, [Paris 1954, Colbert].

do B Kautsky, Karl, Terrorismus und Kommunismus.

Berlin 1919, [Verlag Neues Vaterland].

do B Fülöp-Miller, R[ené], Geist und Gesicht des Bolschewismus, Zürich-Leipzig 1926

Đeutseher, Statine. [Paris 1953, Gallimard]

do B Dallin, [David und Nikolaevsky, Boris], Zwangsarbeit in Sowjetrußland.

Wien 1947, [Neue Welt Verlag].

do B Adoratsky, [V.], Dialectical Materialism,

New York 1934, [International Publishers].

Peter Sager, Die theoret [ischen] Grundlagen

des Stalinismus und ihre

Auswirkungen auf die

Wirtschaftspolitik des Sowjet[unions].

1953 Bern, [Haupt].

$\times \quad$ D. W. Brogan, Le prix de la

Révolution, [Paris 1953], Calm[ann]-Lévy

Maseolo, [Dionys, Le communisme, Paris 1953, Gallimard]

Makarenko, [Anton], Ausgewählte pädag[ogische Schriften, Paderborn 1961, Schöningh].

1 „do B” - „do Berkeley”; oznaczenie książek, które pisarz zamierzał wykorzystać, przygotowując się do zajęć w Berkeley. 
по вторникам и суббот[ам]

од $15^{30}-18$

Pilne:

1) Dokumenty (materiały) XIX Zjazdu w ZSRR, w 1952, możliwie po polsku w szczególności: Przemówienie Stalina na XIX zj[eździe] broszura Stalina Zagadnienia gospodarcze socjalizmu $w$ ZSRR

2) Dokumenty XXII Zjazdu (może „Nowe Drogi” ewent[ualnie] po rosyjsku)

3) Stary Testament w[edlu]g możliwe X[iędza] Wujka

4) Jakaś polska monografia o pawłowizmie

do B

Barrington Moore Jr., Soviet Politics. The Dilemma of Power. Harvard 1956.

do B

Merle Fainsod, Comment l'URSS est gouverné. [Paris 1957, Éditions de Paris].

B

J. Towster, Political Power in the USSR 1917-47. [New York 1948], Oxford Univ[ersity] Press

do B

Hannah Arendt, The Origins of Totalitarianism. [New York 1951, Hartcourt].

Serbin Evg[enij] Političeskije nastrojenia $w$ sowietskoj armii [v poslestalinskij period] (Istočniki [Issledovanija i materiały]. [Institut] po izuczeniu SSR) München, 1956

Fh[omas] J. Blaekeley, Soviet Seholas [tieism. Dordreeht 1961, D. Reidel].

Do B N[icolas] Rutych, La partie communiste au povoir en URSS [19171960]. [Paris 1961], Table Ronde.

od nowej kartki

Nadto; do biblioteki

Suzanne Labin, Vie ou mort du monde libre. [50 témoinages]. Éd. Table Ronde, [Paris] 1961.

[Bertrand] Russell, Bolshevism in Theory and Practice [The Practice and Theory of Bolshevism. London 1921, G. Allen \& Unwin]. 
„Sovietica. Studies in Soviet Thought”. Part I. Uniw[ersytet] we Fryburgu (m.in. szkic Lobkowicza)

R[ichard] V[oyles] Burks, The Dynamics of Communism in Eastern Europe. Princeton Univ[ersity] Press. [Princeton] 1961.

Daniels, R[obert] V., The State and Revolution. [A Case Study in the Genesis and Transformation of Communist Ideology. „American Slavic and East-European Review", February 1953].

P[ierre] Hervé, La revolution et les fetiches. Table Ronde, Paris 1956.

[Maurice] Merleau-Ponty, Les aventures de la dialectique. [Paris] 1955, [Gallimard].

Do Ber[keley] Edg[ar] Morin, Autocritique. [Paris] 1959, [R. Juillard].

J[ulius] Martov, Le bolchevisme mondial. [Paris] 1934, [Société d'éditions „Nouveau Prométhée"].

Columbia University, The Anti-Stalin Campaign and International Communism. [A Selection of Documents]. [New York] 1956, [Columbia University Press].

Do B [erkeley] F[ranz] Borkenau, European Communism. Faber \& Faber, [London] 1953.

Do Berk[eley] E[rnest] J. Simmons, [ed.], Continuity and Change in Russian and Soviet Thought. Harvard [Univeristy Press, Cambridge, Mass.] 1955.

[Alex] Inkeles \& [Raymond A.] Bauer, [The Soviet Citizen:] Daily Life in Soviet Union [w1.: in a Totalitarian Society]. Harvard [Univeristy Press, Cambridge, Mass.] 1959.

$142 \mathrm{E}$ [eonard Bertram] Sehapiro, The Origin of the Communist Autocracy: [Political Opposition in the Soviet State, First Phase], 1917-1922. Bell \& S[ons], Eondon] 1955.

720 Head of statue of king Mentuhotep III, XI dyn[asty], 2300 b[efore] Ch[rist]

(popierał teatr [?] 
Turgieniew

Marr

Аввакум

Щапов, Истор[ические] очерки [народного] миросозер[иания и] суеверия Berkeley Ткачов Berk[eley]

Roman Lady as Venus

Victrix, a palm in her left hand, a dove at her foot

$111 \mathrm{~A}[\mathrm{nno}] \mathrm{D}$ [omini]

Lion from the side of a

doorway in the palace

of Assur-Nasir-Pal, Ass[yria] 885-860

[A. A.] Amfiteatrov, Одержсимая Русь, [Берлинъ]1929

[Georgij] Iwanow, Петербургские зимы, Париж 1928

Korniejczuk

Maksimov, Нечистая, неведомая и крестная сила, [С.-Петербург] 1903

Marr, Избранные работы, t. I-V 4496

Ber[keley] Tourgueneff N[icolaï], La Russie et les Russes, t. 1-3

Iwanow-Razumnik, Писательские судьбы, [Paris] 1847 New York 1951

Berk[eley] Ист[ория] русской общественной мысли. Индив[идуализм] и мещанство [в русской литературе и жизни XIX века],

[Donald] Mackenzie Wallace, La Russie, Paris 1879

С[анкт-]Пет[ерсбург] 1911

Moszyński Kazimierz, Kultura [ludowa] Stowian, t. II Kultura duchowa

Ivan le Terrible

[Polska] Ak[ademia] Um[iejętności], Kraków 1939

Berkeley Щапов А[фанасий] П., Исторические очерки народного миросозерцания и суеверия [(православного и старообрядческого), 1863]

Правдоискание, beguins, Halévy [?] 
La Messug[uière]

Blonde1, Psychologie collective

B

$\mathrm{B}$ [ondel], L'action (science de la pratique)

Boèce, La consolation philosophique

$\mathbf{P}$

Bréhier, Histoire de la philos[ophie] 2 to[my]

[Bréhier,] Les thèmes actuels de la philosophie $\quad \mathbf{C}$

Léon Brunschvicg, Le rôle du pythagorisme dans l'évolution des idées

Burnham, L'Ère des organisateurs

Caillois, L'homme et le sacré

Camus, L'homme revolté $\quad \mathbf{P}$

Carra de Vaux, Les penseurs de l'Isla $[\mathrm{m}] \quad \mathbf{P}$

Cioran, Précis de décomposition

Desoille, Le rêve éveillé en psychothérapie

Durkheim, [Les] formes élémentaires de la vie religieuse $\mathbf{B}$

Eliade, Le Mythe de l'éternel retour

Traité d'histoire des religions

Fichte, Initiation à la vie bienheureuse

Freud, Totem et tabou

B

\section{La Messug[uière]}

Ét. Gilson, La philosop[hie] au moyen-âge

$\mathbf{P}$

Jean Grenier, Le Choix

Halbwachs, La mémoire collective

Hegel, Leçons sur la philosophie de l'histoire

Heidegger, De l'essence de la vérité

Huizinga, Le Déclin du Moyen-âge Homo ludens

$87 \quad$ B

86

David Hume, Traité de la nature humaine 2 v[olumes]

Vladimir Jankélévitch, Traité des vertus $\mathbf{P}$

L'Ironie ou la bonne conscience

André Joussain, Psychologie des masses

B

Jung, Psych[ologie] de l'inconscient $\quad \mathbf{P}$

Kant, Critique Opera posthuma

Prolegomene

Kierkegaard, Ou bien... ou bien $\quad$ P

In vino veritas

Klages, Les principes de la caracterologie 
La Mess[uguière]

Lalande, Vocabulaire

Leibnitz, Oeuvres chois[ies]

$\mathrm{Lefebvre,} \mathrm{La} \mathrm{somme} \mathrm{et} \mathrm{le} \mathrm{reste} 2 \mathrm{t}$ [omy]

B

Lévy Bruhl, La mythologie primitive $1 / 6 \quad$ B

Le surnaturel et la nature dans la ment[alité] primit [ive]

J. Marquès-Rivière, Histoire des doctrines ésotériques $\mathbf{P}$

K. Marx, Oeuvres politiques 8 tomów

Misère de la [hilosophie], Manifeste $\quad \mathbf{P}$

Correspondence avec Engels $9 \mathrm{t}[\mathrm{om}]$

Maucorps, Psychologie des mouvements sociaux

Thierry Maulnier, Mythes socialistes $\quad \mathbf{P}$

Merleau Ponty, Avent[ures] de la dialect [ique]

Humanisme et terreur $\mathbf{B}$

Nietzsche, Le gai savoir

La Messug[uière]

Nietz[sche], La naissance de trag[édie]

La volonté de puissance

Lotus de Pa[i] ni, Les Trois totemisations, $1924 \quad$ A

Pavlov, Typologie et pathologie de l'activité nerveuse suppér[ieure] $\mathbf{A}$

$\mathrm{Piaget,}$ [Jean] Piaget, La répres[entation] $d u$ monde chez [l']enfant A

Prenant, Biologie et marxisme

Pseudo Denys, Oeuvres complètes

Rivaud Albert, Histoire de la philo[sophie] $3 \mathrm{t}$ [omy]

de Rougemont, Penser avec les mains

St. Anselme, Oeuvres philosophiques

St. Augustin, Soliloques

Sartre, L'imaginaire

\section{Les Confessions}

L'imagination

Scheler Max, L'Homme du ressentiment

Seneca, Dialogues

B

B

P 
La Messug[uière]

Spengler Osw[ald], Le Déclin de l'Occident

Tilquin, Le Behaviorisme $\quad \mathbf{B}$

Toynbee, La Civilisation à l'épreuve

Weil Sim[one], La Pesanteur et la Grâce B

La Source grecque

La connaissance surnat [urelle]

Serie E

Butler, Nouveaux Voyages en Erewhon

Daumal René, La grande beuverie

Du Bos, Approximations

Flaubert, Bouvard et Pecuchet

$\mathbf{P}$

Gide, Ainsi soit-il

Gide, Les caves du Vatican

Hervé P., La Révolution et les fétiches

B

Joyce, Ulisses

$\mathrm{J}[\ddot{u}]$ nger, $H[e ́]$ liopolis

$\mathrm{Kafka}$, Le chateau

B

La Colonie pénitentiaire

Journal intime

Machiavel, Nicolas, Oeuvres politiques

$*$

La Messu[guière]

Machiavel + Anti-Machiavel

B

K[arl] Mehnert, La jeunesse en Russie sov[ietique]. B

Valery Larbaud, [Oeuvres]

Papini, Le Diable

Paulhan Jean, Le Guerrier appliqué $\mathbf{P}$

Pellico, Mes prisons $\mathbf{P}$

St Simon, Mémoires

Sade, Justine B Spr

〈Sartre〉 Sartre, Situations

Stirner, Max, L'Unique et sa propriété

A

Valéry, Variété II

Spr

Regards sur le monde actuel

A 
J u ng, Die Psychologie der unbewussten Prozesse B

J o s e ph B e rn har t, Die philosoph[ische] Mystik des Mittelalters [von ihren antiken Ursprüngen bis zur Renaissance] B

Do znalezienia

William Graham Sumner

(o out-group'ach) Do Be[rkeley]

$4^{\circ} \mathrm{Pc} 1420$ (II)

$\mathrm{BN}$

Padre Anton-Sepp

Viagem

as misses

jesuiticas

e trab

apostolicos $^{2}$

Sao Paolo 1951

R. Fülöp-Miller, Les Jésuites et le secret de leur puissance. Plon

$16^{\circ}$ H. 304

Sepp, Reisebeschreibung und Kurzer Berich der Denkwurdigsten Sachen. Nuremberg 1697

\section{Do Ber[keley]}

M. Florinsky, The End of the Russian Empire. New Haven, Conn. 1931

BN Heinrich Popitz, Der entfremdete Mensch 1953

$8^{\circ}$

Bas. ph. 1943

172 str.

Hugh Seton-Watson, The pattern of communist revolution. Methuen

Eleutherius Winance O. S. B., The Communist Persuasion.

New York 1959

2 Właśc. Viagem às Missões Jesuiticas e Trabalhos Apostólicos. 
Stalin tom $\mathrm{X}$

Ważne szukać (Jeleński) $\quad$ 8/I 62

Mordecai Oren, Prisonnier politique à Prague Édit. Julliard

Paléologue, La Russie de[s] tsars, t. II, s. 119

Jaspers, Psychopathologie générale, p. 571, 585

J. Delay, Les dissolutions de la mémoire

E. L. Bouvier, Le Communisme chez les insect[e]s Berkeley

Sighele, Psychologie des sectes 〈po rosyjsku〉Berkeley

(Blondel: nat [uralisme] à ramener toute civilisation au vol

ou à la violence)

Podręcznik savoir vivre' u dworskiego

Pascal cytuje obok Epikteta,

? Montaigne: Salomon de Tultie ?

(Fables[?])

przejrzeć Es cobara

Lucien [Lyttelton?], Fontenelle

odnaleźć coś do

dialogu Staline - Lenine

Popławski M[ieczysław] St[anisław], Polityczna publicystyka w dobie Cezara i Augusta, Lublin (TN KUL) 1935, str. $3058^{\circ} 2$ 30564(6) Do Berk[eley]

$\mathrm{B}[\mathrm{i}] \mathrm{b}[$ lio]g[rafia]: (o szczerości) 
F. L. Arnaud, Sur la sincérité des certains délirants. „Journal de Psychologie” № 19 (1922),

p. 557-566 - uwagi P[ierre'a] Janeta

B [i]b[1io]g[rafia] (o snach więźniów)

$\mathrm{P}$ [ierre-]M[axime] Schuhl, [Jeux des i]mages captives, w: Le merveilleux, la pensée et l'action $\langle\mathrm{Pa}[\mathrm{ris}]\rangle$ Flammarion 1952 do ks

Przekład

Hölderlin

Fragment

Das Angenehme dieser Welt hab' ich genossen, die Jugendstunden sind, wie lang! wie lang! verflossen, April und Mai und Julius sind ferne, Ich bin nichts mehr, ich lebe nicht mehr gerne.

\section{S. 295}

Wyd[anie] E[ugen] Diederichs, Jena 1905

Rudolf Kassner, Das physiognomische Weltbild

W dżungli klatka z kozłem przywiązanym, drzwi otwarte,

w a żne (Falltur) - kozioł 〈krzyczy, panter[a]〉. Na krzyk kozła pantera wskakuje, drzwi się zamykają. Nazajutrz to samo

z inną klatką i panterą - ale koza jest ta sama pantera/leopard

jej nie pożarł mimo głodu) nie dotknął.

$\mathrm{K}$ [assner] thumaczy, że z zapadającymi drzwiami

wola pantery oddziela się od jej duszy - przedtem

stanowiła jedno - na wolności. (Wille - Seele)

Teoria (kontemplacyj[na]) - Maria, praxis - Marta.

Henri Decugis, Le vieillissement $d u$ monde vivant, Plon, 1941 
Hipoteza biologiczna monophylétique

„[Et] cette période de création ne semble pas, en l'état actuel de nos connaissances, s'être répétée par la suite. Les groupes réalisés et diversifiés se sont épanouis plus ou moins tard, ont duré plus ou moins et on $[t]$ régressé, certains s'etaignant totalement, d'autres ne laissent que quelques vestiges; certains formes on $[t]$ subsisté depuis des epoques les plus anciennes sans guère varier. La Nature actuelle est ainsi l'ensemble des vestiges $d u$ passé (przed[mowa] M[aurice] Caul[1] ery de l'Ac[ademie] des Sciences)

[dopisek z lewej strony:] $\mathrm{jak}$ w społeczeńst[wie] ludzkim

Les variations qui se produisent et que l'expérience permet de regarder comme n'étant pas purement individuelles, sont plutôt la manifestation de virtualités implicites d'une constitution stable, variations que les circonstances et un déterminisme infiniment complexe en son de tail amènent à s'extérioriser et qui paraissent ainsi résulter du hasard.

Les necessités de l'existence et les actions réciproques des espèces et des individus, opèrent sur ce matériel une æuvre d'élimination par voie de sélection.

[przy pierwszych dwóch zdaniach dopisek z lewej strony:] Jak w społeczności ludzi.

Sowiecki c złowiek. Ho e s s [ostatnie zdanie zakreślone z lewej strony podwójną kreską]

Kwestia zgodności lub niezgodności = adekwatności struktury naszej świadomości ze strukturą Natury jest w ostatecznym [rachtnktu]ości sprawą równie tajemnicą jak geneza i mechanizm adaptacji w biologii, największa tajemnica biologii. Pomysły biologów przypominają jako takie 
En travesti ,, in pappafico” (en capule)

Nic[colo] Mac[hiavelli] à Francesco Vettori (ambas[sadeur $])^{3}$

Je vis donc dans ma maison de campagne. Odkąd jeszeze po trudach we Floreneji. Voici donc comment je vis. Je me lève avec le soleil, et je vais à un de mes bois que je fais couper; j'y reste 2 heures à revoir la besogne du jour écoulé et à tuer le temps avec mes bûcherons: ils ont toujours quelque querelle en cours (...). En quittant mon bois, je m'en vais à une fontaine et de là à ma volière. J'emporte un livre sous le bras, tantôt Dante, tantôt Pétrarque (...), Tibulle, Ovide (...): je me plonge dans la lecture de leurs amours et leurs amours me rappellent les miennes;

(...) Je gagne ensuite l'auberge sur la grand [e] route: je m'entretiens avec ceux qui passent, (...) j'observe la variété des goûts et la diversité des caprices des hommes. (...) Sitôt déjeuné, je fais retour à l'auberge: il y a là d'habitude avec l'aubergiste, un boucher, un meunier et deux chaufourniers. C'est avec ces gens-là que tout l'après-midi je m'encanaille à jouer tun au tric-trac, à la cricca, jeu dont s'ensuivent mille contestations et des querelles

à l'infini à grand renfort d'injures;

et la plupart du temps, c'est pour un enjeu d'un quattrino (...)

$C$ 'est dans une pouillerie pareille qu'il me faut plonger pour empêcher ma cervelle de moisir tout à fait; c'est ainsi que je me défends de la méchanceté de la Fortune envers moi, presque content qu'elle m'ait jeté si bas et curieux de voir si elle ne finira pas par en rougir.

Le soir tombe, je retourne au logis. Je pénètre dans mon cabinet et, dès le seuil, je me dépouille de la défroque de tous les jours, couverte de fange et de bous boue, pour revêtir des habits de cour royale et pontificale; ainsi honorablement accoutré, j'entre dans les cours antiques des hommes de l'Antiquité. Là, accueilli avec affabilité par eux, je me repais de l'aliment qui par excellence est le mien, et pour lequel je suis né. (...) Et, durant 4 heures de temps, je ne sens pas le

3 Toutes les lettres de Macchiavel. Paris 1955, Gallimard. 
moindre ennui, j'oublie tous mes tourments, je cesse de redouter la pauvreté, la mort même ne m'effraie pas. Tu napisał o De principatibus.

\section{esperienza delle cose moderne}

Gdy „filozofia” - miłość prawdy, mądrości była tylko służką teologii, teologia była właściwie filozoteą fito teofilią, miłością do Boga.

Ist Od czasu gdy ludzkość wyszła ze stadium naiwnego realizmu, gdy umysł, wyższa czynność nerwowa, uzyskał samodzielność i nadrzędność - co niewątpliwie było w zasadzie greeko wkładem Grecji, niewątpliwie czerpiącej z ezoteryki Wschodu, nastąpiła dysjunkcja Miłości i Prawdy, i nastę[pne] próby ich pokornego łączenia byly mistyezne wyjaśniają sens doświadczeń mistyeznyeh wszystkich kierunków i eksponentów mistycyzmu, arabskiego, muzułmańskiego, hinduskiego jak i chrześcijańskiego.

Płaskość, wulgarność, trywialność (poszłost') myśli, smaku i stylu, zupełnie nie przesądza sprawy wielkiego Artysty. Primo zasadniezo $\mathrm{W}$ takim zagadn pojęciu płaska i poczuciu, co jest płaskie i wulgarne zależy od tego, kto ocenia, tzn. od naszego poziomu i systemu kultury, jej poziomu, i co Ala ze stanowiska jednej kultury jedynego jest płaskie, ze stanowiska innego jest szczególnie autonome [?], więcej - ma być wzniosłe, tak kiedy Goethe 0 Wolter o Szek[spirze] a nawet Goethe o Szekspirze dla wyrafinowanej, w rokokowych finezjach, neoklasycznej wzniosłości smaku i poetyki Woltera a nawet

- gdy nam znowu Wolter jest bezwstydnie płaski 
i chamski (i nie jest to sprawa postępu w czasie, bo nie jest nim Diderot ani Goethe). Po drugie w ogóle płaskość i trywialność nie jest degraduje bynajmniej poetów mniejszych minores, ale bynajmniej nie degraduje wielkich artystów twórców, w sztuce bowiem niestety, co wolno wojewodzie, to nie tobie smrodzie, czasami odwrotnie, przydaje im wielkości. Brutalność, trywialność Stalina - Rembrandt sztokholmski ${ }^{4}$ (p[atrz] Andrzej Wat ${ }^{5}$ ) Claudius, jego oko jest szkaradą, ale majestatyczny, groźny, ale łomki jakby z gliny, nieprawdziwy, simulakrowy (dzieło Artysty jest zawsze simulakrem, jest tylko ma pozory istnienia)

seksualizm

Zdaję sobie sprawę, jak szokująca jest moja propozycja:

Stalin-Artysta. Ale najpierw jak dziwny jest rozum artysty - zacznę od pomieszania dwóch (czy więcej) zupełnie niespójnych znaczeń: artysty-imitatora, więc aktora, poety, pisarza-naśladowcy, stylisty, słowem kopisty, do tego narcyza; i artysty twórcy jedyne właśeiwie tzn. demiurgowego, twórcy. Oczywiście mam na myśli tylko Kiedy Neron powiedział (albo i nie, Salust[iusz]) Qualis artifex pereo, nie mo-mógł chyba mieć na myśli swojego kabotyństwa, swoich występów, ale swoje czyny i działania, dla których Rzym był tworzywem, w którym wszystko jest po tylko materią jego pot[rzeby] idearium, form jego i ślepych skłonności jego duszy, ale jego potrzeby tworzenia.

Stalin chciał być kochany. Strach religijny, obłęd, że on zawsze ma rację, że zatem wszyscy są wobec niego, nikt nie jest przed nim bez winy. Zakładał, że taka miłość jest możliwa - tę wiedzę czerpał z religijnego swego dzieei[ństwa] lat Tu jego koncepcja - to Pamiętaj oderint, dum metuant ulubione powiedzenie Kaliguły (Swetoniusz)

4 Spisek Klaudiusza Cywilisa z 1661 roku - Nationalmuseum, Stockholm.

5 Chodzi o tekst syna poety, Andrzeja: A. W a t, Rembrandt, czyli o nowoczesności. „Nowa Kultura" 1957, nr 46. 
było jego dyrektywą jego wykonawców, sttk helfershelfer'ów, Chrusz[czowa]

\section{Ważne (u Lefebvre’a)}

słynne zdanie z przemówienia Lenina na II kongresie Komsomołu: „Walka klas trwa dalej i najważniejszym obowiązkiem jest wszystko jej podporządkować. Podporządkujmy jej naszą moralność komunistyczną. Powiadamy:

moralne jest to, co przyczynia się do zniesienia starego społeczeństwa wyzyskiwaczy i do łączności (union) wszystkich pracujących w o k ó 1 proletariatu, budowniczego nowego społeczeństwa komunistycznego".

Lefebvre un mélange the inéxtricable de bonne et de mauvaise commence

Niechęć do socjologii Lefebvre La somme et le reste / 545

Le parti refuse de se eond considérer et d'être considéré sociologiquement, d'être étudié sociologiquement est posé même virtuellement comme objet d'étude sociologique.

[Dopisek z lewej strony:] „Le parti se veut le maître de la science, et non objet de science".

[Dopisek z prawej strony:] od 47 lat now moralność kol [icz]estwa

T. E. Lawrence, Seven Pillars of Wisdom

Les sept piliers de la sagesse, Payot 1942

$37,49,51,53,54,56,58,59,62,64,109$

$119,129,217-18,220,221,234,336,337,409-410$

$434,444,446,501,503,597,633,635$

(ekstazy

„Les faibles envient leurs compagnons assez

fatigués pour nourrir, car le succès apparaissait

lointain et l'échec offrait un repos assuré, quoique a tro ce (chap [itre] I, str[ona] 37 [wł. 38]) [et] ${ }^{6}$ nous en arrivions à vivre seulement

6 Łączący oba fragmenty spójnik „et” został dopisany przez Wata zamiast opuszczonego 
pour l'horizon visible, en casse-cous, insouciants des souffrances infligées ou subies puisque toute sensation phys ique apparaissait petitement passagère. Des bouffées de cruauté, de perversion, de luxure couraient à la su rface de notre vie sans la troubler: car les lois morales qui élevaient naguère leurs barrières autour d'accidents puérils apparaissaient comme des mots plus faibles encore que les sensations. Il y a avant, apprenions nous, des chocs trop aigus, des souffrances trop profondes, des extases trop hautes pour que nos «moi» finis les enregistrassent. À cette acuité d'émotion l'esprit perdait haleine et la mémoire pâlissait jusqu'au retour de circonstances plus banalement quotidiennes.

Une telle exaltation de la pensée, laissant l'esprit aller à la dérive et lui donnant essence en d'étranges climats, lui faisant perdre en même temps sa vie[i]lle autorité sur le corps. (...) En conséquence, nous mîmes le corps au rebut;

\section{2}

nous le laissâmes au-dessous de nous pour aller en avant, simulacre animé, abandonné à son propre niveau, soumis à des influences que nos instincts eussent évitées en temps normal (str[ona] 38)

„La peine d'exister était si grande que la peine de punir devait être impitoyable".

[akapit zakreślony z lewej strony potrójną kreską:] „L'homme qui accepte d'être possédé par des étrangers mène la pire vie d'esclave parce qu'il a vendu son âme à une brute. [Lui-même n'est pas un de ces étrangers.] Il peut donc s'opposer à eux, croire à sa mission, tordre et forger cette matière humaine, lui donner une forme qu'elle n'eût jamais prise seule: dans ce cas il se sert des forces de son propre milieu naturel pour faire sortir du leur ces étrangers. Ou bien il peut, comme je l'ai fait, les imiter si bien qu'à leur tour

urywka: „Nous vivions, les nerfs toujours tendus ou brisés, tantôt sur la crête et tantôt au creux des vagues émotives. Une telle faiblesse nous était amère;" 
ils l'imitent. L'homme qui agit aussi

abandonne son propre milieu: il prétend

à celui d'autrui; et les prétentions sont

vaines. [42]

(Stalin jedno i drugie)

Lafolie ,est proche, je crois, de tout homme qui peut voir simultanément l'univers à travers les voiles des deux coutumes, de deux éducations, de deux milie ux". (43)

(Stalin, udany Lawrence'a w potędze)

Gruzin-Rosjanin, Đeutseher brat[anek] siostrzeniec Swanidze [?], wymowa gruzińska, wahania między biegunami, patriotyzm rosyjski i pogarda dla Rosjan, dla ich czynów, dla niewolniczej natury, Pugaczow był nie czysto rosyjskim zjawiskiem.

Rosja jest czymś tak wyróżniającym się, taką plamą na mapie psychologii światowej (uniwersalną, tak jaskrawo i odmiennie zarysowaną, że w zetknięciu z Rosjaninem, nie tylko zachodni ludzie, ale i ludzie wschodu okreśtają widzą ją j[ako] duszę rosyjską zagadkowo, ale jako jednolitą; $z$ drugiej strony - wszęedzie cała tkanka życia, obyczajów, pochodzenia, wierzeń, jest rze $\mathrm{z}$ różnych zupełnie odrębnych Przyp Nadużycie to z pomieszania Ukraińców, Gruzinów, Czuwaszów z Rosjanami sensu stricto, ale nawet gdy się weźmie samych Rosjan, pozostaje tkanka heteroklityczna.

Lawrence: Ayant dépouillé une forme sans en acquérir une nouvelle, j'étais devenu semblable au légendaire cercueil de Mohammed. Le résultat 
devait être un sentimentd'intense solitude, accompagné de mépris non pour les autres mais pour tout ce qu'ils font. (43)

(Obce elementy engloutis par les fortes caractéristiques de la race autochtone [45])

(sekret spójności Kozaków): la plus mordante et la plus profonde des disciplines sociales, le no madisme (- wbrew przyjętym opiniom ( $p[$ age $] 49)$

universelle netteté ou dureté de chap $[$ itre $] 3$ croyance, quasi mathématique dans ses limites et repoussante dans sa forme par l'absence de sympathie.

ce peuple voit le monde [sous des couleurs primaires, ou, mieux encore, ] en contours decoupée noir sur blanc. Son esprit dogmatique méprise le doute[, notre moderne couronne d'épines] [49-50]

Sa pensée n'est à l'aise que dans les extrêmes. Par goût elle se loge dans les superlatifs. Parfois, à quelque articulation de la pensée, deux contradictoires s'emparent des Arabes au même instant; ils n'acceptent pas pour cela de comprenus. Sans percevoir la moindre incongruité, ils pousssent à l'absurde, avec logique, leurs opinions incompatibles.

La tête froide, le jugement tranquille, dans une imperturbable inconscience de leur oscillation, ils volent d'asymptote à asymptote.

Chap $[$ itre $] 3$ (50)

Arabowie pretendują, że dali światu 40000 proroków; historia zna kilka setek

Aby prorok mógł osiągnąć swój cel, potrzebuje des amas d'âmes sèches prêtes à l'incendie 
„On entraîneraint les Sémites, [il est vrai,] aux quatre coins du monde [(mais non au ciel)] sans croyance, rien qu'en leur montrant

les richesses et les plaisirs de la terre. Mais qu'ils rencontrent sur leur route le prophète. d'une idée, sans toît pour abriter sa tête et sans moyens de subsistence que la chasse ou la charité, ils le suivront aussitôt en abandonnent leurs richesses".

Fatma i Hassan, 900 lat panowania w Mekce, szeryf emir (szeryf szeryfów) 2000 potomków Mahometa [por.: 62]

J e h a d = Wojna Święta Muzułmanów przeciw Chrześcijanom [por.: 64]

26

Sztuka wojenna:

Napoleon, C 1 a u s e w it z, Caemmerer,

Moltke, Jomini, Willisen, Maré chal de Saxe anihiler l'ennemi [236]

von Golz: annithiter] briser son courage [236]

Polityka

la transposition au $X X^{e}$ siècle des

guerres de réligion, dont la conclusion

logique était la destruction complète

d'une croyance et dont tous les protagonistes

pensaient que le Jugement de Dieu prévaudrait

à la fin (238) chap [itre] 33

(Sowiety prowadzą i narzuciły światu zachodniemu wojnę religijną

- pilna potrzeba laicyzowania, nadanie wojnie

jej charakteru laickiego (analog[icznie] ,wojna absolutna”

Focha)

$\mathrm{B}$ [i] b [1 i o] g [ra fi a] F o ch

la guerre absolue: deux nations professant

des philosophies incompatibles mettaient

leurs doctrines à l'épreuve de la force. [237]

ideał brytyjski: armia profesjonalna

$\mathrm{Cl}$ a u s e w it z - wyliczył kategorie wojen 
$\mathrm{B}[\mathrm{ardzo}]$ wa żne

Xenofont: diathétique =l'art de Cyrus avant

son attaque: 1) psychologia thumu, który trzeba zmobilizować

i prowadzić do akcji; 2) psychologia jednostek =

un jeu d'émotions consciemment choisies [244]

(Spr[awdzić] u Ksenof[onta]. Dwie wielkie taktyki Stalina:

1) psychologia zbiorowa; 2) psychologia

indywidualna (imponderabilia)

Podobnie wg tego schematu: a) wewnątrz; b) na zewnątrz

$\mathrm{B}[\mathrm{i}] \mathrm{b}[$ liografia] K s e n o fo $\mathrm{nt}$

Notre diathétique devait considérer la capacité émotionelle de nos hommes, leur complexité, leur humeur changeante.

Nous devions cultiver en eux tout ce qui pourrait un jour nous servir; disposer leurs esprits en ordre de bataille avec autant de soin et de méthode [que d'autres officiers disposeraient leurs corps]. [244]

szkoła rekruta, szkoły podoficerskie

imitacja bywa kom[plementem] może być uważana za prawdę albo za komplement

Transkrypcja: Adam Dziadek

Jan Zieliński

\begin{abstract}
ADAM DZIADEK

(University of Silesia, Katowice)

\section{ALEKSANDER WAT'S NOTEBOOKS FROM BEINECKE LIBRARY}

Aleksander Wat's notebooks are held in the collection of the author's archive materials of Beinecke Rare Book and Manuscript Library at Yale University (New Haven, USA) and form a part of Aleksander Wat Papers. The pieces, written at the turn of 1950s and 1960s, are a unique treasure for any Aleksander Wat scholar. Found in a rich archive collection, they are prepared for publication by Adam Dziadek and Jan Zieliński within the framework of Notatniki Aleksandra Wata - spiralna nielinearność zapisu (Aleksander Wat's notebooks - a spiral non-linearity of record). The present volume offers its transcript and description.

No-one ever tried to decipher them, superficially regarding their insignificance for Wat's output or, which is more probable, due to enormous difficulties with their decoding. The work with the notes which prove to be a peculiar type of "pre-texts" is carried out in accordance with literary genetic criticism. The transcription and preparation is here linked with a special type of repetition. What was hidden in the darkness of library is repeated and starts a new life. That proves to be the seminal case as far as the co-creation of cultural heritage of one of the most outstanding $20^{\text {th }}$ century poet is concerned.
\end{abstract}

